\title{
Michał Kokowski
}

Instytut Historii Nauki im. L. i A. Birkenmajerów PAN

michal.kokowski@gmail.com

\section{Odpowiedź na list \\ Dr. Pawła E. Tomaszewskiego na temat badań życiorysu Jana Czochralskiego}

\begin{abstract}
Streszczenie
Autor udziela odpowiedzi na list Pana dr. Pawła E. Tomaszewskiego, będącego kolejnym (trzecim) etapem polemiki na temat faktów z życia Jana Czochralskiego i różnic w sposobie ich przedstawiania przez amatora i profesjonalnego historyka. Źródłem kontrowersji jest biografia pt. Powrót. Rzecz o Janie Czochralskim (2012), edycja angielska: Jan Czochralski restored (2013).

Zdaniem Autora, profesjonalny historyk nauki może mieć pewne zastrzeżenia wobec czasami zbyt popularnego stylu publikacji dr. Tomaszewskiego. Nie ulega jednak żadnej wattpliwości, że jak dotąd to właśnie ten Amator [tj. miłośnik, entuzjasta] badań historycznych dokonał znacznie więcej na polu badań
\end{abstract}

\begin{tabular}{|c|c|c|c|c|c|}
\hline \multicolumn{2}{|c|}{$\begin{array}{l}\text { INFORMACJA } \\
\text { O PUBLIKACJI }\end{array}$} & $\begin{array}{l}\text { Pistoriae } \\
\text { cientiarum }\end{array}$ & $\begin{array}{r}\text { e-ISSN 2543-702X } \\
\text { ISSN 2451-3202 }\end{array}$ & $\left(\begin{array}{ccc}3 \\
3\end{array}\right.$ & $\begin{array}{l}\text { } \\
\text { BRYLANTOWY MODEL } \\
\text { OTWARTEGO DOSTĘPU }\end{array}$ \\
\hline \multicolumn{6}{|c|}{$\begin{array}{l}\text { CYTOWANIE } \\
\text { KOKOWSKI Michał 2016: Odpowiedź na list Dr. Pawła E. Tomaszewskiego na temat badań życiorysu Jana } \\
\text { Czochralskiego. Studia Historiae Scientiarum 15, ss. 405-408. } \\
\text { DOI: } 10.4467 / 23921749 S H S .16 .019 .6162 \text { Dostęp online: http://pau.krakow.pl/SHS/shs-15-2016-19.pdf }\end{array}$} \\
\hline \multicolumn{3}{|c|}{$\begin{array}{l}\text { OTRZYMANO: } 21.12 .2015 \\
\text { ZAAKCEPTOWANO: } 12.10 .2016 \\
\text { OPUBLIKOWANO ONLINE: } 24.11 .2016\end{array}$} & $\begin{array}{c}\text { POLITYKA } \\
\text { ARCHIWIZOWANIA } \\
\frac{\text { Green SHERPA / }}{\text { RoMEO Colour }}\end{array}$ & $\begin{array}{l}\text { LICENCJA } \\
\text { (c) (i) } 6 \text { ( })\end{array}$ & \\
\hline WWW & \multicolumn{5}{|c|}{ http://pau.krakow.pl/Studia-Historiae-Scientiarum/ http://ejournals.eu/Studia-Historiae-Scientiarum } \\
\hline
\end{tabular}


biografii i dokonań Jana Czochralskiego niż profesjonalni historycy i historycy nauki.

Odpowiedź ta kończy polemikę.

Słowa kluczowe: Jan Czochralski • biografistyka • analiza źródet historycznych $\bullet$ amator vs. profesjonalista

\title{
Response to the letter of Dr. Paweł E. Tomaszewski about the studies into the life of Jan Czochralski
}

\begin{abstract}
The author replies to the letter of Dr. Paweł E. Tomaszewski, which is a subsequent (third) stage of the controversy regarding the facts of life of Jan Czochralski and the differences in the way they are presented by an amateur researcher and a professional historian. The source of the controversy is the biography Powrót. Rzecz o Janie Czochralskim (2012), the English edition: Jan Czochralski restored (2013).

In the opinion of the author, a professional historian of science may have some reservations regarding the sometimes too popular a style of the publications of Dr. Tomaszewski. Nevertheless, there is no doubt that so far this amateur [i.e. enthusiast] of historical research has done much more regarding the biography and achievements of Jan Czochralski than professional historians and historians of science.

This reply concludes the exchange of polemics.
\end{abstract}

Keywords: Jan Czochralski $\bullet$ biographical research $\bullet$ analysis of historical sources $\bullet$ amateur vs. professional historian

W pełni zgadzam się z Panem dr. Pawłem E. Tomaszewskim ${ }^{1}$, że stosowanie aparatu krytycznego nie polega jedynie na podaniu odsyłaczy literaturowych. Jednakże podanie właścinych odsyłaczy literaturowych jest konieczne, aby umożliwić uważnemu Czytelnikowi (odbiorcy naszych

\footnotetext{
${ }^{1}$ Tomaszewski 2016, s. 397.
} 
publikacji) sprawdzenie tez głoszonych przez Autora publikacji lub podjęcie własnych badań $i$ analiz.

W pełni też podzielam przekonanie Autora, że problem źródeł bistorycznych nie jest wcale prosty. Zapewniam również, że profesjonalny historyk musi być świadomy istnienia różnych kategorii źródeł, nie może ich traktować równoprawnie oraz - co bardzo ważne - musi je ujawniać w swoich publikacjach, gdyż bez spełnienia tego ostatniego warunku przedstawiane przez nas interpretacje zdarzeń historycznych niebezpiecznie upodobniają się do fikcji literackiej (był to jeden z powodów, który sprawił, że podjąłem polemikę z Autorem).

Cieszy mnie więc np. jasna wypowiedź Autora w sprawie redaktora Bratkowskiego:

red. Bratkowski nie prowadził żadnych badań. Jego stwierdzenia dotyczące okoliczności ewakuacji Czochralskiego do Polski bazuja ayłacznie na wiedzy wyniesionej z własnego domu².

Podobnie ucieszyła mnie ogólna deklaracja Autora dotycząca potrzeby poszukiwania rzetelnych źródeł i umiejętnego posługiwania się nimi w konstruowaniu narracji historycznej ${ }^{3}$ oraz krytyka w tym duchu mojej wypowiedzi o studiach Jana Czochralskiego, nie poparta jednak przeze mnie wskazaniem odpowiednich źródel ${ }^{4}$. Największą zaś przyjemność sprawiła mi lektura podanej przez Autora listy najważniejszych publikacji na temat Jana Czochralskiego. Dostęp do nich umożliwia bowiem wnikliwemu Czytelnikowi podążanie śladami dotychczasowych badań

Mając to wszystko na względzie, podtrzymuję moją zasadniczą tezę, konsekwentnie głoszoną we wszystkich fazach tej polemiki. Zawodowy, profesjonalny historyk nauki może mieć pewne zastrzeżenia wobec czasami zbyt popularnego stylu publikacji Pana dr. Pawła E. Tomaszewskiego. Mimo to, nie ma wątpliwości, że ten właśnie Amator (czyli miłośnik, entuzjasta) badań historycznych dokonał znnacznie więcej

${ }^{2}$ Ibidem, s. 398; zob. też Kokowski 2014, ss. 135-136.

${ }^{3}$ Tomaszewski 2016, s. 397, punkt 3.

${ }^{4}$ Tomaszewski 2016, s. 398, w zakończeniu punktu 3.

${ }^{5}$ Tomaszewski 2016, s. 399, punkt 6 . 
na polu badań biografii i osiagnięć Jana Czochralskiego niż zawodowi / profesjonalni historycy i historycy nauki ${ }^{6}$.

Kończąc tę polemikę, życzę Panu dr. Tomaszewskiemu dalszych owocnych badań.

KOKOWSKI Michał

\section{Bibliografia}

2014: $\quad$ Komentarz do artykułu dr. Pawła Tomaszewskiego. Prace Komisji Historii Nank PAU XIII, ss. 131-140. Publikacja dostępna online: http:// pau.krakow.pl/PKHN-PAU/pkhn-pau-XIII-2014-8.pdf (dostęp 28.09.2016).

2015: Uwagi do komentarza dr. Pawła E. Tomaszewskiego na temat badań życiorysu Jana Czochralskiego (Replika). Prace Komisji Historii Nauk. PAU XIV, ss. 283-288. Publikacja dostępna online: http://pau.krakow. pl/PKHN-PAU/pkhn-pau-XIV-2015-12.pdf (dostęp 28.09.2016).

TOMASZEWSKI Pawel E.

2012: $\quad$ Powrót. Rzeczo Janie Czochralskim. Wrocław: Oficyna Wydawnicza ATUT. ISBN 978-83-906218-6-9, ISBN 978-83-7432-817-3.

2012-2016: Biuletyn Roku Czochralskiego 1-166. Wrocław. Publikacja dostępna w Internecie: http://www.janczochralski.com/ (strona internetowa redagowana przez Sylwestra Czochralskiego) (dostęp 28.09.2016).

2013: Jan Czochralski Restored. Wrocław: Oficyna Wydawnicza ATUT. ISBN 978-83-7432-945-3.

2014: Jan Czochralski - historia człowieka niezwykłego. Prace Komisji Historii Nanki PAU XIII, ss. 57-72. Publikacja dostępna online: http://pau.krakow.pl/PKHN-PAU/pkhn-pau-XIII-2014-4.pdf (dostęp 28.09.2016).

2015: Uwagi do komentarza prof. Michała Kokowskiego o badaniach życiorysu Jana Czochralskiego. Prace Komisji Historii Nanki PAU XIV, ss. 275-281. Publikacja dostępna online: http://pau.krakow.pl/PKHNPAU/pkhn-pau-XIV-2015-11.pdf (dostęp 28.09.2016).

2016: Uwagi do komentarza prof. Michała Kokowskiego o badaniach życiorysu Jana Czochralskiego. Studia Historiae Scientiarum 15, ss. 395404. Publikacja dostępna online: http://pau.krakow.pl/SHS/shs-152016-18.pdf (dostęp 24.11.2016).

\footnotetext{
${ }^{6}$ Kokowski 2014, s. 138 punkt 6; 2015, s. 286, punkt 4.
} 